\title{
SOCIAL IDENTITY IN SERIOUS SPORT EVENT SPACE
}

\author{
INSUN SUNNY LEE,* GRAHAM BROWN,* KATHERINE KING,† AND RICHARD SHIPWAY† \\ *School of Management, University of South Australia, Adelaide, South Australia \\ †Faculty of Management, Bournemouth University, Talbot Campus, Fern Barrow, Poole, UK
}

\begin{abstract}
Sport events offer valuable experiences in distinctive settings, and serve as settings for social identity formation. Drawing on the literature from a range of disciplines, events characteristics are seen to provide spaces for the cocreation of values, liminality, communitas, flow experiences, and authenticity. It is suggested that sport events facilitate career progression in relation to serious leisure and the development of social identification. This article provides further insight about the nature of event experiences with implications for event management.
\end{abstract}

Key words: Serious leisure; Serious sport tourism; Sport event; Event experience; Event travel career trajectory

Introduction

The growing literature about events has documented the growth in sport events (Alexandris \& Kaplanidou, 2014; Derom, VanWynsberghe, \& Scheerder, 2015) and the type of experiences they offer (Derom \& Taks, 2011). However, there has been less discussion about the factors that give rise to these experiences. This article provides a conceptual analysis of the way event spaces shape experiential outcomes. It discusses the implications of these experiences for serious participants in sport events (Derom \& Taks, 2011) by reviewing the literature about serious leisure (Stebbins, 1992) and the notion of an event career trajectory (Getz, 2008). Four key concepts, associated with event-related theories, are used to help explain the role of sport events in the formation or reinforcement of social identity. Practical implications for sport event management are discussed and recommendations are made for future research about the relationship between sport events and participation in serious leisure.

\section{Serious Leisure and Sport Events}

The concept of serious leisure was introduced by Stebbins (1992) as "the systematic pursuit of an amateur, hobbyist, or volunteer core activity that is highly substantial, interesting, and fulfilling and where, in the typical case, participants find a career in acquiring and expressing a combination of its special skills, knowledge, and experiences" 
(p. 3). The concept of serious leisure offers a framework that can be used to argue that leisure could go beyond a simple recreational or free-time activity, and be associated with unique values. The concept has been applied in different leisure contexts (C. A. Brown, 2007; Cheng, Patterson, Packer, \& Pegg, 2010; Hartel, 2010), and has been explored in sport activity (Bartram, 2001; Dilley \& Scraton, 2010), sport tourism (Kane \& Zink, 2004), and, recently, in sport events (Getz \& McConnell, 2011; Shipway \& Jones, 2007, 2008).

The term "serious sport tourism" was used by Green and Jones (2005) when it was suggested that event participation can encourage and facilitate career development and progression in a sport activity. It involves the interrelationship between serious leisure, social identity, and subculture in a sport tourism context (Green \& Jones, 2005). Previous studies have suggested that sport events provide serious sport participants with a positive and enhanced social identity, and offer a space for them to interact with others based on their leisure identity (Getz \& McConnell, 2011; Lamont \& McKay, 2012; Miller, 2012; Shipway \& Jones, 2007, 2008). Miller (2012) discusses the reinforcement of a sense of identity through the extreme physical challenge of event participation and the support provided by the home club association, family, fellow participants, and the general crowd at the event. Miller's (2012) study examined the experiences of triathletes at a long distance triathlon event. Coghlan and Filo (2013) found similar outcomes in a study of community-focused sport events.

Serious leisure has been defined with six characteristics to distinguish it from casual leisure: a need to persevere in the activity; the development of a long-term career path; significant personal effort in the activity; realization of various special and durable benefits; a unique ethos and social world; and identification with the activity (Stebbins, 1992). A number of studies (Jones, 2000; Shipway \& Jones, 2007) have placed particular emphasis on the sixth characteristic, social identification with the activity, in order to further understand the behaviors of serious leisure participants. It has been argued that social identity could be the starting point for the development of serious leisure. Once social identity is established, the other five characteristics could serve to strengthen social identity. Based on these arguments, this study focuses on social identity with respect to serious leisure, and conceptualizes the relationship between sport event space and serious leisure.

\section{Social Identity}

Social identity theory is based in social psychology and is concerned with why people identify with and act in social groups (J. Turner, 1975). Identities are made up of both personal and social aspects (Green, 2001). Personal identity is how people identify themselves as being a unique individual, different to the rest of the world, whereas social identity is how people identify with a social group. Social identity can have a strong influence on motivations and behaviors (Delbosc, 2008; Green, 2001). Delbose (2008) found that a desire to meet members of the community was the most common motivation to visit a cultural festival among community members, whereas learning about the community was the most common motivation for noncommunity members. Similarly, Green (2001) found different motivations and behaviors during an event between general event visitors and those who have a strong social identity with the subculture. For example, it was found that motorcyclists attending a Grand Prix sought opportunities to parade and celebrate the subculture associated with motorcycling with their social group at the event.

It has been argued in the social psychology literature that there are two processes involved in social identity formation: self-categorization/identification and social comparison (Stets \& Burke, 2000). Selfcategorization/identification is a process in which individuals categorize and classify themselves in particular ways in relation to their social categories, and recognize themselves as a group member, whereas the social comparison process involves categorizing persons who are similar to the self as the in group and persons who differ from the self as the out group. The two processes have different consequences in relation to identity formation (Stets \& Burke, 2000). The consequence of selfcategorization/identification is an emphasis on the perceived similarities between the self and other in-group members, and an emphasis of the perceived differences between the self and out-group members. On the other hand, the consequence of 
the social comparison process is the selective application of the accentuation effect, primarily to those dimensions that will result in self-enhancing outcomes for the self. Specifically, one's selfesteem is enhanced by evaluating the in group and the out group on dimensions that lead the in group to be judged positively and the out group to be judged negatively.

These processes suggest that social identity is formed based on self-evaluation and self-recognition, and Weiss (2001) claims that self-evaluation, selfrecognition, and self-esteem are rooted in social recognition as they are influenced by the way an individual adopts the recognition of others in relationship to the self. Weiss (2001) also argues that sport participants can receive social recognition and consequent identity reinforcement through displays of dexterity, skill, strength, knowledge, and intelligence. It suggests that the opportunity to find social acceptance and confirmation, and gain social recognition could be an essential value that attracts sport participants to attend sport events.

\section{Event Travel Career Trajectory}

The type of events that are preferred by serious sport participants have been discussed in relation to an event travel career trajectory (Getz \& Andersson, 2010; Getz \& McConnell, 2011). The notion of an event travel career trajectory was proposed by Getz (2008), who derived it from the concept of travel career trajectory (Pearce \& Lee, 2005), which argues that travel motivations change with respect to travel experience level. The event travel career trajectory suggests that people engaged in serious leisure are likely to develop event-specific travel careers as they become more highly involved. The event travel career trajectory provides an explanation for the motivations of people highly involved in leisure or sport activity and provides patterns of their event tourism. It is argued that as involvement in a particular sport increases, an event travel career changes across six dimensions that constitute a pattern of travel that will clearly distinguish the highly involved from general tourists and lesser-involved event goers (Getz \& Andersson, 2010; Getz \& McConnell, 2011).

The first dimension of the event travel career concerns motivation. The highly involved are motivated by self-actualization needs. Travel style is the second dimension and the highly involved tend to travel to more events and to spend more time making travel plans. The third and fourth dimensions are related to the time and location of events with the highly involved exhibiting less seasonality and traveling farther and for longer periods of time. The fifth dimension is event type; the highly involved participate in events that are novel and prestigious. The last dimension is destination and event choice; the highly involved have different criteria for selecting events and destinations compared to the less involved. Serious participants are attracted to events that are well-organized but with challenging and interesting routes (Getz \& Andersson, 2010; Getz \& McConnell, 2011; Shipway \& Jones, 2007). The choices made by serious sport participants provide opportunities to achieve self-actualization and enhance self-esteem through goal achievement and ego enhancement.

Although these six dimensions of the travel pattern of serious sport participants are widely acknowledged, Lamont, Kennelly, and Wilson (2012) claim that the choice of events is contingent upon their availability and the intensity of "the competing priorities” (p. 1071). The highly involved may still participate in local and low-profile events as preparation for more challenging events or as a consequence of "pulsation" (p. 1077). This finding implies that local, small, and low-profile events attract serious sport participants for different purposes and reasons. The values that events offer to participants to facilitate the development of serious leisure can be as important as the profile and size of events. This calls for an understanding of the features of sport events that enable participants to create value for their career progression in relation to serious leisure. Such understanding could help event managers enhance the attractiveness of events by creating and managing event spaces in ways that accentuate the characteristics that support the development of serious leisure.

\section{Sport Event Space and Social Identity Formation}

Drawing on previous studies, this article now presents four characteristics of sport events that may influence the formation of social identity: spaces that promote the cocreation of experiences 
and values, liminality and communitas, flow experiences, and authenticity.

\section{Cocreation of Experiences}

In the business literature, cocreation occurs in markets where interactions between active customers and firms create joint personalized values (Prahalad \& Ramaswamy, 2004). It is not the firm trying to please the customer; rather customers coconstruct experiences to suit their context. The values arise in the form of personalized, unique experiences reflecting a move towards consumer centricity. Individuals play the main role in shaping their personal experiences and values.

In tourism, which is part of the service economy (Pine \& Gilmore, 2011), tourists participate in experience networks (Binkhorst \& Den Dekker, 2009). They can cocreate their tourism experiences before, during, and after travels by engaging with tourism service providers, local residents, attractions, and technology (Internet). Prebensen and Foss (2011) suggested that the tourism industry must provide high-quality starting points to encourage tourists to participate in the cocreation of experiences. Prebensen, Vittersø, and Dahl's (2013) quantitative research demonstrated that high levels of active participation generated the greatest value for tourists. They also found that cocreation experiences give an opportunity for tourists to shape and create their identity. This view could equally apply to event participants.

Events occur in cocreated experiential environments in which event participants construct personalized experiences. Events are no longer a simple service or entertainment; rather they act as spaces for event participants to have their own experiences within the event settings. The services and products that the event provides may be the same for all participants, but participants construct different experiences and create different values depending on the way they engage with event settings. The concept of eventscapes has been used to describe the role of event settings in relation to event experiences. When discussing the spatial scope of a cycling event, G. Brown, Lee, King, and Shipway (2015) defined an eventscape as the range of "settings which facilitate and add value to the event" (p. 7) to include specific event sites and the broader environment that provides scenic backdrops. The boundaries are determined by where people decide to perform event-related behaviors; not just by markings and fences created by organizers. Personalizing the cocreation experience means fostering individualized interactions and experience outcomes (Prahalad \& Ramaswamy, 2004). A personalized cocreation experience reflects how the individual chooses to interact with elements of the eventscape.

For event participants, sport events offer a special time and space (Getz, 2007) where they can construct their own experiences. By interacting with event offerings, with the atmosphere and with other people, personal meanings and values can be created that respond to the individual needs and wants. Events offer not only core products, such as a cycling program at a participatory cycling event, but also augmented products such as sport-related exhibitions, social programs, and entertainment. Through active engagement with core and augmented event products, the cocreated experiences and derived values are various and personal. The enjoyment of a particular sport-related atmosphere created by the event in the presence of a social group may be accompanied by a celebration of subcultural values (Green \& Chalilp, 1998). Other outcomes include excitement from the energized atmosphere created by crowds (Lamont \& McKay, 2012; Miller, 2012) and learning or sharing sport-related information with other participants. Cocreation encourages a more active involvement leading to value-rich experiences that can fulfill needs and wants. The need to be recognized as a member of a group of sport enthusiasts could be fulfilled by participating in the sport activity and by communicating with other participants on the field and in a social setting such as a bar afterwards (Weiss, 2001). These created values serve to reinforce social identity.

\section{Liminality and Communitas}

No matter where events are held, at a purposebuilt event venue such as an arena or stadium, or in an ordinary space transformed into an event space, events temporarily create special spaces for event experiences that are different from everyday 
experiences (Johansson \& Kociatkiewicz, 2011). In this vein, Falassi (1987) views festivals as a time that is out of ordinary time and Getz (2007) argues that event experiences are time out of time within a special place. The notions of liminality and communitas (V. Turner, 1982) have been employed to understand event experiences outside the normal routine.

Liminality was developed in the field of anthropology to explain the phases in the tribal ritual processes where an ambiguous state is created by participants (V. Turner, 1982). Liminoid is a term V. Turner (1982) developed to describe a temporary state during the change associated with liminality, but in secular rather than sacred terms, and it has been broadly used to describe political and cultural change, and the temporary state in the change. Communitas, as the temporary state of communal human relationship, is identified as one of the ambiguous states constructed through liminality or during the liminoid phase (V. Turner, 1982). Communitas describes a special sense of togetherness that exists outside ordinary social structure where participants have something very specific in common and build temporary relationships among themselves within the group.

Event academics such as Getz (2007) acknowledge that event practices contain a liminoid phenomenon as an event is an experience occurring outside normal social processes, and event participants can experience the transient state, including communitas, during an event. In the sport event context, the unique ethos associated with a particular sport such as distinctive dress, language, and behavior become acceptable as normal practices within a sport event space. Participants are able to experience a transformation of the identity that exists in their daily life (Shipway \& Jones, 2007) due to the liminality created by an event. This makes it possible to be involved more deeply and more intensively in a sport within the event space. The liminal characteristics of event space were illustrated in Shipway's (2012) study by using the term "third place" (p. 208). His findings suggest that running events provide space for serious runners to become part of a different world away from the ordinary life, in the home and work environment. These places encourage casual sociability and strengthen the feeling of belonging and recognition as a member of a social group, with consequent implications for social identity reinforcement.

The engagement with an event can generate a subculture in which individuals with diverse social backgrounds are gathered around the shared core values associated with a particular sport, creating communitas among participants. In Coghlan and Filo's (2013) study of charity cycling events, being part of "pseudo-families" (p. 127), made up of strangers with common interests, was found to be meaningful and to form a subculture based on their social identity with cycling. A sense of camaraderie (Lamont \& McKay, 2012; Miller, 2012; Shipway, 2012) is also commonly mentioned as one of factors that can make participants want to return to an event. Communitas serves to reinforce identity (Hannam \& Halewood, 2006) and strengthen the in-group and out-group distinction (Kim, 2005). Thus, the shared sport experiences at an event can increase the emotional intensity of links among participants and affirm the social identity in relation to serious leisure.

\section{Flow Experiences}

Flow theory is based on the idea that people are most happy when they are in a state of concentration or complete absorption with an activity, that is, in a state of flow (Csikszentmihalyi \& Csikszentmihalyi, 1988). Flow is a state of consciousness that is sometimes experienced by people who are deeply involved in an enjoyable activity. While a state of communitas indicates a group phenomenon, flow is associated with individual experience.

Events have the capability of generating flow experiences in which an individual stands outside of self (Kim, 2005). The flow experience represents an extraordinary experience different from the common pleasures of everyday life. Participants can have flow experiences through deep involvement, intense concentration, and transcendence of self during the event period within the setting of the event, away from their other commitments. They may undergo a variety of self-transcending experiences at an event that could lead to a sense of accomplishment or transformation. A sense of accomplishment and 
transformation are seen as distinctive characteristics of serious leisure (Stebbins, 1992) and mastery (e.g., a challenge to abilities) has been identified as one of the dominant motives for participation in sport events (Lamont \& Jenkins, 2013).

There exists a distinct difference between an event space and everyday space in terms of the intensity of experiences because of the liminal characteristics of the event space. However, the effects of flow experiences gained through event participation do not just remain in the event space, but extend into everyday life. Coghlan and Filo (2013) found that a participatory cycling event space provides an individual with an opportunity to connect with the individual self, for example, through a physical challenge. They argue that the space allows individuals to express their better self, highlighting the presence of a greater goal and reflecting the event as a mechanism toward selfexpression, inspiration, and accomplishment. So, the enhanced social identity through achievement of a stronger sense of accomplishment may extend into the home environment and everyday life.

\section{Authentic Experiences}

Authenticity has been a popular topic in tourism (Cole, 2007; Connell, 2007; Xie, 2003) and in the events literature (Carnegie \& McCabe, 2008; McCartney \& Osti, 2007). It has been argued that tourism development turns culture into a commodity and creates many events to cater to tourists' wants, resulting in a loss of authenticity and the creation of pseudoevents (Boorstin, 1961). However, sport events have been considered as providing authentic experiences (Hinch \& Higham, 2005) as they provide different experiences every time. This perceived authenticity is due to the uncertainty of outcomes, the role of athletic display, the kinaesthetic nature of sport activities, and the tendency for strong engagement in sport. The authenticity of sport events makes ordinary space symbolic and valued, and motivates serious sport participants to actively participate to build a leisure/sport career. Authentic experiences such as seeing athletes in the flesh, taking a direct part in the sport at a valued event space, and having access to "behind the scenes” (Lamont \& McKay, 2012, p. 326) reinforce commitment to the activity, and help build subcultural capital (Green \& Jones, 2005).

The perishability characteristic of events as a service experience also enhances authenticity. No matter how often an event is produced, the event experiences of a specific event are only available at a specific time and cannot be experienced again (Getz, 2007). A particular occurrence of an event experience, such as a famous win by a favorite team, presents authentic personal stories that contribute to develop an individual's sense of identity (Clark \& Salaman, 1998; Shipway \& Jones, 2007).

The behaviors of event participants, such as purchasing event merchandise or wearing clothing that shows previous attendance at events, are associated with the authentic nature of events. Event merchandise can be used to display an association with an event, held at a particular place, and at a specific time. This may demonstrate levels of event involvement, linked to an event career, level of skill, or knowledge and an ability in relation to the specific sport. These behaviors allow participants to present their identity to others, and develop their identity simultaneously through emphasizing similarities between the self and other in-group members and differences between the self and out-group members (self-categorization/identification), and allowing themselves to be recognized by others in the in group (social comparison).

\section{Conclusions and Implications}

This article has made a critical analysis of key literature to demonstrate that event participation provides valuable outcomes for serious participants. Social identity can be reinforced due to the cocreation of experiences with liminal, flow, and authentic experiences having the potential to be transformative. This turns sports event settings into serious sport event spaces, which make possible career progression in relation to serious leisure. A summary of the nature of sport events as spaces for forming social identity is presented in Table 1 .

A contribution to knowledge has been made by linking theories about leisure, tourism, and events to provide further insight about the nature of event experiences but, in addition, the article has practical implications for event management. Firstly, 
Table 1

Events as a Serious Sport Event Space for Social Identity Formation

\begin{tabular}{|c|c|c|}
\hline Theoretical Construct & Nature of Event & Social Identity Formation in Serious Sport Event Space \\
\hline Value cocreation & $\begin{array}{l}\text { Events as a created environment } \\
\text { in which event participants are } \\
\text { active agents in the construction } \\
\text { of personalized experiences }\end{array}$ & $\begin{array}{l}\text { Personal experiences through interacting with the event } \\
\text { setting, program, and other people } \\
\text { Creation of personal meanings and values to event } \\
\text { experience } \\
\text { Creation of personal stories associated with the event } \\
\text { and experiences }\end{array}$ \\
\hline $\begin{array}{l}\text { Liminality and } \\
\text { communitas }\end{array}$ & $\begin{array}{l}\text { Event experience as time out } \\
\text { of time within a special place } \\
\text { (Getz, 2007) }\end{array}$ & $\begin{array}{l}\text { An identity transformation from a work or family } \\
\text { related identity to a serious sport identity } \\
\text { Generation and celebration of a subculture }\end{array}$ \\
\hline Flow theory & $\begin{array}{l}\text { Event's ability to generate flow } \\
\text { experiences for participants }\end{array}$ & $\begin{array}{l}\text { Deep involvement, intense concentration, and self- } \\
\text { transcending experience } \\
\text { Achievement of a sense of accomplishment and } \\
\text { transformation }\end{array}$ \\
\hline Authenticity & $\begin{array}{l}\text { Authenticity of sport and sport } \\
\text { events } \\
\text { Perishability of events }\end{array}$ & $\begin{array}{l}\text { Reinforcement and development of subcultural capital } \\
\text { Generation of personal stories that demonstrate levels } \\
\text { of skill, knowledge, and ability in a sport }\end{array}$ \\
\hline
\end{tabular}

events need to provide programs that encourage people to be actively engaged with meaningful elements of the eventscape to facilitate the cocreation of meaningful experiences and cultural values. The provision of augmented products at the event, such as socialization programs, should be key elements of participatory sport events (Green, 2001) as they offer additional opportunities to reinforce social identity. Secondly, the liminal nature of events could be further exploited to promote communitas and the identity transformation of participants. Event design can be used to enhance the liminality of the setting, to disengage people from their daily life, and to increase the emotional intensity of links with other participants. This is finding expression when event organizers and destination planners work collaboratively to create a distinctive event "look" in a host city. Thirdly, and consistent with the premise of flow theory (Csikszentmihalyi \& Csikszentmihalyi, 1988), sport event organizers need to achieve a balance between the challenge of the task and the skill of the performer. If the task is too easy or too difficult, flow cannot occur. Both skill level and challenge level must be matched and high; if skill and challenge are low and matched, then apathy results (Csikszentmihalyi, 1997). As the event tourist career trajectory suggests (Getz
\& McConnell, 2011), branding is important as the event image will determine whether appropriate participants are attracted; people who have the necessary motivation and skills to reach a flow state. Fourthly, the perishable nature of events can be further emphasized in marketing and merchandising in order to enhance authentic experiences that, in turn, offer additional value for participants.

This conceptual article helps explain the role of sport events in shaping social identity but there is a need for empirical research to test the proposed relationships. The experiences and behaviors of serious sport tourists in the setting of sport events have been mainly examined by qualitative research techniques such as ethnography (Berridge, 2014; Coghlan, 2012; Lamont \& McKay, 2012; Shipway \& Jones, 2008). Future studies could employ quantitative techniques to investigate perceptions about participation in serious leisure and the extent to which this is facilitated by different types of events. For example, the perceptions of professional participants in an event such as the Tour de France could be compared to those of people participating in a community cycling event by testing the influence of factors such as event prestige. A better understanding of the relationship between sport events and participation in serious leisure would assist 
event organizers to more effectively manage sport events and achieve desired goals.

\section{References}

Alexandris, K., \& Kaplanidou, K. (2014). Marketing sport event tourism: Sport tourist behaviors and destination provisions. Sport Marketing Quarterly, 23(3), 125-126.

Bartram, S. A. (2001). Serious leisure careers among whitewater kayakers: A feminist perspective. World Leisure Journal, 43(2), 4-11.

Berridge, G. (2014). The Gran Fondo and Sportive Experience: An exploratory look at cyclists' experiences and professional event staging. Event Management, 18(1), 75-88.

Binkhorst, E., \& Den Dekker, T. (2009). Agenda for co-creation tourism experience research. Journal of Hospitality Marketing \& Management, 18(2-3), 311-327.

Boorstin, D. (1961). The image: A guide to pseudo-events in America. New York: Harper and Row.

Brown, C. A. (2007). The Carolina Shaggers: Dance as serious leisure. Journal of Leisure Research, 39(4), 623-647.

Brown, G., Lee, I. S., King, K., \& Shipway, R. (2015). Eventscapes and the creation of event legacies. Annals of Leisure Research, 18(4), 510-527.

Carnegie, E., \& McCabe, S. (2008). Re-enactment events and tourism: Meaning, authenticity and identity. Current Issues in Tourism, 11(4), 349-368.

Cheng, E. H. P., Patterson, I., Packer, J., \& Pegg, S. (2010). Identifying the satisfactions derived from leisure gardening by older adults. Annals of Leisure Research, 13(3), 395-419.

Clark, T., \& Salaman, G. (1998). Telling tales: Management gurus' narratives and the construction of managerial identity. Journal of Management Studies, 35(2), 137-161.

Coghlan, A. (2012). An autoethnographic account of a cycling charity challenge event: Exploring manifest and latent aspects of the experience. Journal of Sport \& Tourism, 17(2), 105-124.

Coghlan, A., \& Filo, K. (2013). Using constant comparison method and qualitative data to understand participants' experiences at the nexus of tourism, sport and charity events. Tourism Management, 35, 122-131.

Cole, S. (2007). Beyond authenticity and commodification. Annals of Tourism Research, 34(4), 943-960.

Connell, J. (2007). The continuity of custom? Tourist perceptions of authenticity in Yakel Village, Tanna, Vanuatu. Journal of Tourism and Cultural Change, 5(2), 71-86.

Csikszentmihalyi, M. (1997). Finding flow: The psychology of engagement with everyday life. New York: BasicBooks.

Csikszentmihalyi, M., \& Csikszentmihalyi, I. S. (1988). Optimal experience: Psychological studies of flow in consciousness. Cambridge, UK: Cambridge University Press.

Delbosc, A. R. (2008). Social identity as a motivator in cultural festivals. Visitor Studies, 11(1), 3-15.

Derom, I., \& Taks, M. (2011). Participants' experiences in two types of sporting events: A quest for evidence of the
SL-CL continuum. Journal of Leisure Research, 43(3), 383-402.

Derom, I., VanWynsberghe, R., \& Scheerder, J. (2015). Maintaining physical activity post-event? Case of the Tour of Flanders Cyclo in Belgium. Annals of Leisure Research, 18(1), 25-47.

Dilley, R. E., \& Scraton, S. J. (2010). Women, climbing and serious leisure. Leisure Studies, 29(2), 125-141.

Falassi, A. (1987). Festival: Definition and morphology. In A. Falassi (Ed.), Time out of time: Essays on the festival (pp. 1-10). Albuquerque, NM: University of New Mexico Press.

Getz, D. (2007). Event studies: Theory, research and policy for planned events. Oxford, UK: ButterworthHeinemann.

Getz, D. (2008). Event tourism: Definition, evolution, and research. Tourism Management, 29, 403-428.

Getz, D., \& Andersson, T. D. (2010). The event-tourist career trajectory: A study of high-involvement amateur distance runners. Scandinavian Journal of Hospitality and Tourism, 10(4), 468-491.

Getz, D., \& McConnell, A. (2011). Serious sport tourism and event travel careers. Journal of Sport Management, 25, 326-338.

Green, B. (2001). Leveraging subculture and identity to promote sport events. Sport Management Review, 4(1), $1-19$.

Green, B., \& Chalilp, L. (1998). Sport tourism as the celebration of subculture. Annals of Tourism Research, 25(2), 275-291.

Green, B., \& Jones, I. (2005). Serious leisure, social identity and sport tourism. Sport in Society, 8(2), 164-181.

Hannam, K., \& Halewood, C. (2006). European viking themed festivals: An expression of identity. Journal of Heritage Tourism, 1(1), 17-31.

Hartel, J. (2010). Managing documents at home for serious leisure: A case study of the hobby of gourmet cooking. Journal of Documentation, 66(6), 847-874.

Hinch, T., \& Higham, J. (2005). Sport, tourism and authenticity. European Sport Management Quarterly, 5(3), 243-256.

Johansson, M., \& Kociatkiewicz, J. (2011). City festivals: Creativity and control in staged urban experiences. European Urban and Regional Studies, 18(4), 392-405.

Jones, I. (2000). A model of serious leisure identification: The case of football fandom. Leisure Studies, 19(4), 283-298.

Kane, M. J., \& Zink, R. (2004). Package adventure tours: Markers in serious leisure careers. Leisure Studies, 23(4), 329-345.

Kim, H. (2005). Serious leisure, participation and experience in tourism: Authenticity and ritual in a renaissance festival. Doctoral Dissertation, Texas A\&M University, TX.

Lamont, M., \& Jenkins, J. (2013). Segmentation of cycling event participants: A two-step cluster method utilizing recreation specialization. Event Management, 17(4), 391-407.

Lamont, M., Kennelly, M., \& Wilson, E. (2012). Competing priorities as constraints in event travel careers. Tourism Management, 33(5), 1068-1079. 
Lamont, M., \& McKay, J. (2012). Intimations of postmodernity in sports tourism at the Tour de France. Journal of Sport \& Tourism, 17(4), 313-331.

McCartney, G., \& Osti, L. (2007). From cultural events to sport events: A case study of cultural authenticity in the Dragon Boat Races. Journal of Sport \& Tourism, 12(1), 25-40.

Miller, A. (2012). Understanding the "event experience" of active sports tourists: Long distance endurance triathletes. In R. Shipway \& A. Fyall (Eds.), International sports events: Impacts, experiences and identities (pp. 99-112). London: Routledge.

Pearce, P. L., \& Lee, U. (2005). Developing the travel career approach to tourist motivation. Journal of Travel Research, 43, 226-237.

Pine, B. J. \& Gilmore, J. H. (2011). The experience economy. Cambridge, MA: Harvard Business Press.

Prahalad, C. K., \& Ramaswamy, V. (2004). Co-creation experiences: The next practice in value creation. Journal of Interactive Marketing, 18(3), 5-14.

Prebensen, N. K., \& Foss, L. (2011). Coping and co-creating in tourist experiences. International Journal of Tourism Research, 13(1), 54-67.

Prebensen, N. K., Vittersø, J., \& Dahl, T. I. (2013). Value co-creation significance of tourist resources. Annals of Tourism Research, 42, 240-261.

Shipway, R. (2012). Distance running events and the "third place.” In R. Shipway \& A. Fyall (Eds.), International sports events: Impacts, experiences and identities (pp. 208-220). London: Routledge.

Shipway, R., \& Jones, I. (2007). Running away from home: Understanding visitor experiences and behaviour at sport tourism events. International Journal of Tourism Research, 9(5), 373-383.

Shipway, R., \& Jones, I. (2008). The great suburban everest: An "insiders" perspective on experiences at the 2007 Flora London Marathon. Journal of Sport \& Tourism, 13(1), 61-77.

Stebbins, R. A. (1992). Amateurs, professionals, and serious leisure. Montreal, Quebec: McGill-Queen's University Press.

Stets, J. E., \& Burke, P. J. (2000). Identity theory and social identity theory. Social Psychology Quarterly, 63(3), 224-237.

Turner, J. (1975). Social comparison and social identity: Some prospects for inter-group behaviour. European Journal of Social Psychology, 5, 5-34.

Turner, V. (1982). Celebration: Studies in festivity and ritual. Washington, DC: Smithsonian Institution Press.

Weiss, O. (2001). Identity reinforcement in sport: Revisiting the symbolic interactionist legacy. International Review for the Sociology of Sport, 36(4), 393-405.

Xie, P. F. (2003). The bamboo-beating dance in Hainan, China: Authenticity and commodification. Journal of Sustainable Tourism, 11(1), 5-16. 